\title{
Influence Factors That Consist Of Competence (Knowledge, Skills, Self-Concept and the Individual Characteristics) On Performance Employees in Tamalanrea Makassar
}

\author{
Mukhlis Sufri ${ }^{1}$, Rismawati ${ }^{2}$ \\ ${ }^{1}$ University Moeslem Indoensia \\ ${ }^{2}$ University of Fajar Makassar
}

\begin{abstract}
The purpose of this study was to determine the effect of Competence Against Employee Performance At Tamalanrea District of Makassar. The population in this study is the District Tamalanrea Employees In Makassar City with a sample size 80 people. Methods in collecting data in this study are questionnaires, interviews, and documentation. Methods of data analysis using descriptive and quantitative method with multiple linear regression analysis was used to measure Competence Factor Effect Against Employee Performance At Tamalanrea District of Makassar. Based on F test of independent variables (knowledge-, skills, self-concept and the individual characteristics) jointly have the positive and significant effect on the dependent variable (Performance Officer). Through testing the correlation coefficient $(R)$ is obtained that the degree of correlation or relationship between knowledge-, Skills, SelfConcept and Characteristics of Individuals Against Employee Performance is a high correlation in the amount of $61,8 \%$. While the remaining $39,2 \%$ are influenced by other factors. Knowledge is the most dominant factor influencing Employee Performance At Tamalanrea District of Makassar.
\end{abstract}

\section{Preliminary}

Law Number 43 Year 1999 as amendment to Law Number 8 Year 1974 regarding the Principles of Personnel implied mandate that in the framework of efforts to achieve the national objectives required civil servants who serve as servants of society, with full loyalty to Pancasila and the Law Basic 1945. The role and position of Civil Servants (PNS) is very important and decisive because public servants are elements of the state apparatus in carrying out governmental and developmental tasks in order to achieve national goals.

Performance is the result or level of success of a person as a whole during a certain period in carrying out the task compared with various possibilities, such as standards of work, targets or targets or criteria are determined in advance and has been mutually agreed. From the word performance, according to The Scribner Bantam English Dictionary (in Rivai and Basri, 2005: 14) comes from the root word to perform that has some entries, ie (1) performs, Run, execute (to do or carry out execute); (2) fulfill or perform the obligation of an intent or vow (to dischange of fulfill; as vow); (3) implement or refine the responsibility (to execute or complete an understanding); (4) do something expected by a person or machine (to do what is expected of a person machine). From the input can be interpreted, the performance is to perform an activity and refine the work in accordance with its responsibilities so that it can achieve results as expected.

The quality of human resources (HR) is one factor to improve the productivity of an organization's performance or agency. Therefore, it is necessary human resources who have high competence because the competence will be able to support the improvement of employee performance performance. During this time many government agencies that do not have employees with adequate competence, this is evidenced by the low productivity of employees and the difficulty of measuring the performance of employees in the scope of government agencies. During this performance appraisal employee performance using the List of Job Enforcement Assessment (DP3) in which there are 8 (eight) elements, namely honesty, loyalty, obedience, performance, responsibility, cooperation, leadership and initiative.

Based on the description, the authors feel interested to conduct research by continuing previous research also by the authors about the factors that affect the performance of employees at the Office Tamalanrea Makassar, the authors lift the title "The Influence of Competence On Employee Performance At Tamalanrea District Office Makassar". Employees in this study were employees as a whole who worked in Tamalanrea Subdistrict Makassar. MSDM is a management that specializes in studying the relationships and the role of humans in the organization of a company. The element of MSDM is the human being that is the workforce of the company, the focus that MSDM is studying is only a matter related to human labor alone.

Humans always play an active and dominant role in every organizational activity, because humans become the planning, behavior, and determinant of the realization of organizational goals. Goals can not be realized without an employee's active role even though the tools that the company possesses are so 
sophisticated. Sophisticated tools owned by the company no benefit to the company. If the employee's active role is not opted in. Organizing employees is difficult and complex, because they have the heterogeneous thoughts, feelings of status, desire, and background brought into the organization. Employees can not be regulated and fully controlled as set machinery, capital, or building.

Competence is an ability to perform or perform a job or task based on skills and knowledge and supported by the work attitude demanded by the job. (Palan, 2007: 5) While differences in the meaning of both terms are generally accepted, their use is still frequently exchanged, which causes everyone to have a different understanding. Generally people use the term competence and the like to create their own understanding according to their interests. Etymologically, performance comes from the word performance. Performance is derived from a word to perform that has several entries, ie (1) doing, (2) fulfilling or executing a, (3) carrying out a responsibility, (4) doing something expected by someone. From the input can be interpreted, the performance is to perform an activity and refine the work in accordance with its responsibilities so that it can achieve results as expected. Murphy and Cleveland (1995: 113) say that performance is a quality of taskoriented or job-oriented behavior. Ndraha (1997: 112) says that performance is a manifestation of the popular relationship between society and government. Widodo (2006: 78) said that the performance is to perform an activity and refine it in accordance with its responsibilities with the expected results

Murphy and Cleveland (1995: 113) say that performance is a quality of task-oriented or job-oriented behavior. Ndraha (1997: 112) says that performance is a manifestation of the popular relationship between society and government. Widodo (2006: 78) said that the performance is to perform an activity and refine it in accordance with its responsibilities with the expected results.

Furthermore Gibson (1990: 40) said that a person's performance is determined by the ability and motivation to carry out the work. It is also said that the implementation of the work is determined by the interaction between ability and motivation. Keban (1995: 1) performance is the level of goal achievement. While Timpe (1998: 9) performance is the performance of work, which is determined by environmental factors and behavior management. The result of Timpe research shows that the pleasant working environment is so important to push the most effective and productive performance level of employees in the social interaction of the organization will always be the expectation of subordinate to the boss and vice versa.

\section{Conceptual Framework}

Conceptual framework to be studied in this research is Grand theory of competence Spencer and Spencer theory (in Palan, 2007: 6), describes the five characteristics that form the competence that is: Knowledge, Skills, Self Concept and values, Personal Characteristics and Motives . In accordance with the principal problems and locus of research, the authors limit only 4 of 5 characteristics proposed by Spencer and Spencer in this case the motive in this study is not discussed because of the opinions and theories mentioned above can be summed up so important motivation that can cause, And support the human behavior, in order to work hard and enthusiastically achieve optimal results, then the motive in this study can be studied further and more deeply for the authors themselves as well as other authors, then the variables in this study is the influence of competence on employee performance At Tamalanrea Sub-district Office Makassar. For more details this conceptual framework is as follows:

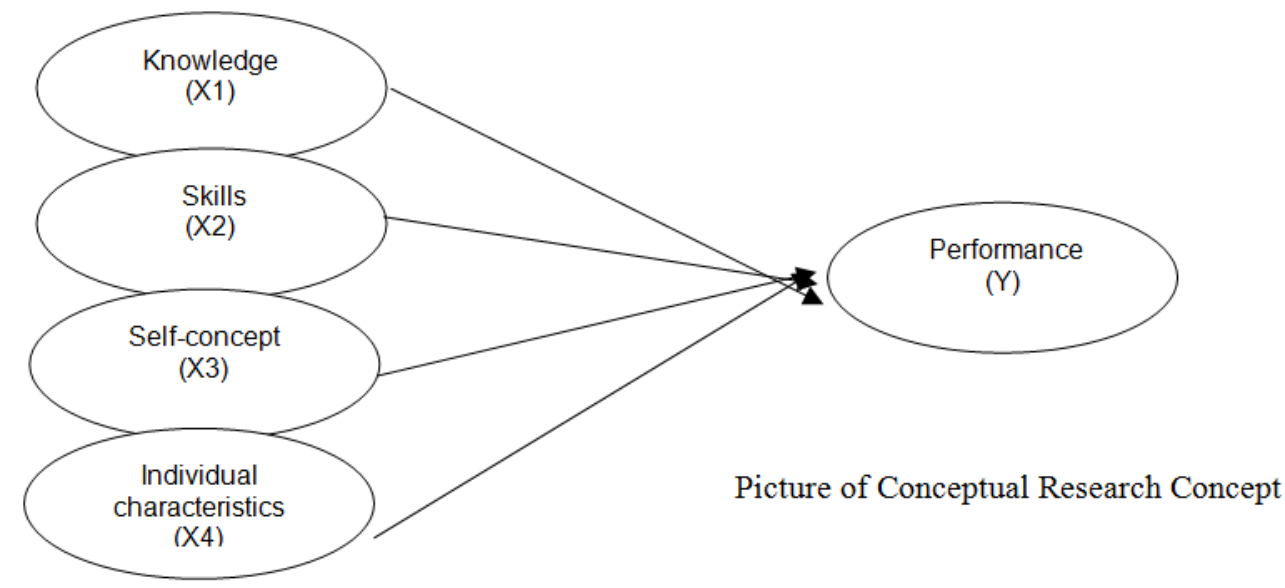




\section{B. Hypothesis}

Hypothesis is a temporary answer to the formulation of research problems (Sugiyono, 2008: 51).

Hypothesis in this research is as follows:

1. It is expected that the higher the knowledge, the higher the employee performance.

2. It is expected that the higher the skill, the higher the employee performance.

3. It is alleged that the higher the concept of self and values, the higher the performance of employees.

4. It is expected that the higher the personal characteristics, the higher the employee performance.

5. It is assumed that the higher the competence of employees (knowledge, skills, self concept and values, and personal characteristics), the higher the employee performance.

\section{RESEARCH METHODS}

\section{Time and Location Research}

This study was conducted pa d a Tamalanrea Makassar District Office. The choice of location is based on the consideration of the acquisition of data and information easily available and do not cost too much, and are relevant to the subject matter which is the object of research.

\section{Types and Data Sources}

\section{Data Type}

The data used in this research are primary data and secondary data, in the form of quantitative and qualitative. Quantitative data in the form of numbers, scales, tables, formulas and so on are a bit much use of mathematics, while the qualitative data in the form of data that can not be measured by numbers or other sizes of the exact nature.

\section{Data Source}

Sources of data have a very important role in the research because with the data source the author will get a source that can be used to know all the information related to the research undertaken. Sources of data that support the answer to the problem in research in the following way:

1. Primary data source

Namely data obtained from the first source, in this case are all employees at the District Office Tamalanrea Makassar.

2. Secondary data source

Namely data obtained from notes, books, papers, reports, archives and other documents.

\section{Population and Sample}

Population is the sum of all objects (units / individuals) whose characteristics are to be expected (Djarwanto, 1998: 107). The population in this study are employees (PNS) on Tamalanrea Makassar District Office with the number 80 . The study sample is part of the population taken as a data source and can represent the entire population. Seeing the total population of 80 people which allows all sampled, so that the method used in this research is the method in which the entire population census was taken as a sample in this research is often called a saturated sample.

\section{Analysis Method}

The method of analysis used to test the above hypothesis is Multiple Regression with the equation:

Information:

$$
Y=a+b 1 X 1+b 2 X 2+b 3 X 3+b 4 X 4+\varepsilon
$$

$\mathrm{Y}=$ Employee Performance

$\mathrm{X} 1=$ Knowledge

$\mathrm{X} 2=$ Skill

$\mathrm{X} 3$ = Self-concept and values

$\mathrm{X} 4=$ Personal Characteristics

$\mathrm{a}=$ Constantic parameters

b1, b2 = Parameter of the Assumption; (Sugiyono, 2006: 243)

The data used in this study consist of primary and secondary data. Primary data is data obtained directly from the field through interviews or by using questionnaires (questionnaires) with respondents (civil servants at the Office Tamalanrea Makassar District).

b0: Constants / intercept

b1 - b5: Regression coefficients / parameters

Ei: The error factor

Furthermore, to determine the effect of independent variables on related variables, either jointly or singly used F-test, $\mathrm{t}$-test and the coefficient of determination $\left(\mathrm{R}^{2)}\right.$ and partially $\left(\mathrm{r}^{2)}\right.$

To test the proposed hypothesis as follows: 
1. Test Validity to indicate the extent to which the measuring instrument hit the thing to be measured, after calculated, the correlation value obtained and compared with the critical number table correlation value $r$. If the correlation value obtained is greater than the criterion table value correlation $r$, then Ho is rejected and Ha accepted. Comparing the correlation number obtained with the correlation table critique numbers $r$ value. If the value of $r>r$ table, then the question is valid or significant in this research, the criterion number of correlation table for $\mathrm{r}$ value is $\mathrm{r}(\mathrm{N}-2 ; \alpha)$. Validity performed using SPSS 21.

2. Test Reabilit as is an index indicating the extent to which the gauges can be trusted or relied upon. Reliability testing technique used is by Cronbac. Cronbach technique used to find the instrument reliability scores range between several values, such as $0-10$ or $0-1000$ or form skal 1-3,1-5 or 1-7 and so on. According Singgih (2000), states that Alpha Croanbach coefficient is between 0 and 1 . The closer to the number 1.0 the better the consistency of the instrument being tested. The Alpha Cronbach coefficient assessment follows the following rules:

Alpha $r>0.9=$ perfect, $_{\text {Alpha }} r>0.8=$ good, $_{\text {Alpha }} r>0.7=$ acceptable, ${ }_{\text {Alpha }} r>0.6=$ questionable, Alpha $r>0.5=$ bad, $r_{\text {Alpha }}<0,5=$ unacceptable. The Reability Test uses the SPSS 21 program.

3. The t test (partial) is used to test the parameters of the regression coefficients of each partial free variable. This means that the test can not determine whether the independent variables individually have a significant impact on the response variable.

The test is:

$\mathrm{H}_{\mathrm{o}} \mathrm{b}_{\mathrm{i}}=0$ (factor $\mathrm{X}_{\mathrm{i}}$ is not influenced $\mathrm{Y}$ )

$\mathrm{H}_{\mathrm{i} ;} \mathrm{b}_{\mathrm{i}}=0$ (factor $\mathrm{X}_{\mathrm{i}}$ affecting $\mathrm{Y}$ ), if an $\mathrm{X}$ factor has an effect on $\mathrm{Y}$, if the value of ${ }_{\mathrm{t}}$ is greater $\mathrm{t}_{\text {table }}$ or calculated probability value is smaller than $\alpha(\alpha=5 \%)$. The influence here means that there is resistance to $H$ o. Sedagkan opposite if smaller ${ }_{t}$ value $t_{\text {table }}$ or a probability value count is greater than $\alpha(\alpha=5 \%)$, then menunujukkan factor $\mathrm{X}$ has no effect on $\mathrm{Y}$.

${ }_{\mathrm{t}}>\mathrm{T}_{\text {table }}$ or $\mathrm{P}$ value $<\alpha$; Reject $\mathrm{H}_{\mathrm{o}}$

$\mathrm{t}<\mathrm{t}_{\text {table }}$ or $\mathrm{P}$ value $>\alpha$; Accept $\mathrm{H}_{\mathrm{o}}$

4. F test (simultaneous test) was used to test the suitability of the model simultaneously whether education and training, employee incentives motivas $\mathrm{i}$ and influence on employee performance. A factor $\mathrm{X}$ will affect $\mathrm{Y}$ is greater than $F_{\text {table, }}$ then at least one $X$ affect $Y$. Meanwhile, if $F_{\text {count }}$ is smaller than $F$ table, then none $X$ dipastikantidak affecting $Y$. If further elaborated:

Htiung $\mathrm{F}<\mathrm{F}_{\text {table }}$ then $\mathrm{H}_{\mathrm{o}}$ accepted, meaning that $\mathrm{X}$ factor together did not significantly affect $\mathrm{Y}$.

$\mathrm{F}_{\text {count }>} \mathrm{F}_{\text {table }}$ then $\mathrm{H}_{\mathrm{o}}$ rejected, meaning that at least one $\mathrm{X}$ factor that significantly affect $\mathrm{Y}$.

5. To see the close relationship anatar independent variable (independent variable) on the dependent variable (dependent variable) is explained by the correlation coefficient $(\mathrm{R})$ if the value of $\mathrm{R}>0.5$ means a strong relationship, $\mathrm{R}=0.5$ means that the relationship was and $\mathrm{R}<0.5$ Means weak relationship.

6. To estimate the percentage of dependency dependent variable (dependent variable) and the constant interskep described by the coefficient of determination $\left(\mathrm{R}^{2)}\right.$ or (R-square) and if the effect of the excluded Interskept $\mathrm{R}^{2}$ to $\mathrm{R}^{2}$ correlated (Adj. R-Square). The value of $\mathrm{R}^{2}$ shows the coefficient of determination is how much the dependent variable changes caused by changes in the independent variables together.

\section{Testing $\mathbf{H}$ ipotesis}

\section{Result And Discussion Result}

Berdas a Refresh on the results of classic assumption test including normality test, multicollinearity test, and test heterokedastisitas showed that the estimated regression has qualified classical assumptions that the expected outcome will be good to analyze the influence of independent variables on the dependent variable. Testing of regression result obtained was tested simultaneously by using F-test and partial test by using t-test. Then it can be described for more details

\section{Hypothesis testing}

\begin{tabular}{|c|c|c|c|c|c|c|}
\hline \multicolumn{7}{|c|}{ coefficients $^{\text {a }}$} \\
\hline \multirow{2}{*}{\multicolumn{2}{|c|}{ Model }} & \multicolumn{2}{|c|}{$\begin{array}{c}\text { Unstandardized } \\
\text { Coefficients }\end{array}$} & \multirow{2}{*}{$\begin{array}{c}\text { Standardized } \\
\text { Coefficients } \\
\text { Beta }\end{array}$} & \multirow[t]{2}{*}{$\mathrm{T}$} & \multirow[t]{2}{*}{ Sig. } \\
\hline & & B & Std. Error & & & \\
\hline \multirow[t]{5}{*}{1} & (Constant) & 5.485 & 4.418 & & 1.241 & .218 \\
\hline & Knowledge_X1 & 1.059 & .422 & .257 & 2.509 & .014 \\
\hline & Skills_X2 & .661 & .231 & .258 & 2.865 & .005 \\
\hline & Concept_Diri_X3 & 1.021 & .388 & .291 & 2.632 & .010 \\
\hline & Characteristics_Personal_X4 & .614 & .419 & .144 & 1.464 & .147 \\
\hline
\end{tabular}

Source: SPSS output that is processed, 2017

Based on the partial test as in the table above shows that the knowledge, skills, self-concept / attitude and personal characteristics significant and positive impact on the performance of employees at the District Office Tamalanrea Makassar. It can be seen from the value of $\mathrm{t}$-arithmet obtained greater than t-table or $\mathrm{t}$-count

DOI: 10.9790/487X-1906044551 $\quad$ www.iosrjournals.org $\quad 48 \mid$ Page


is smaller than t-table. The analysis also showed the four variables that effect, turns variable employee's skills has dominant influence in improving employee performance at the District Office Tamalanrea Makassar, this can be seen from the value of $t_{\text {arithmetic }}$ skills of 2,865 is greater than the value of the t's self-concept 2,632 and the value of ${ }_{t}$ of knowledge is greater than the value $2.509{ }_{t}$ of personal characteristics 1.464 .

\section{Influence of Knowledge ( $X_{1)}$ Against Employee Performance Tamalanrea Makassar District Office}

From the data analysis using the SPSS 21 program indicates that the knowledge variable with the partial r 0.257 with sig. 0.014 which means that knowledge has a significant and positive influence on employee Performance at Tamalanrea District Office Makassar. This shows that the improvement of employee performance is determined by the knowledge that must be owned by an employee in an agency. Good knowledge will lead to an increase in the ability of employees. According to Miftah Toha (1983: 316), the ability which is one of the elements of kematngan related to the knowledge and skills that can be obtained from lathan education or experience. In general, the work done by a person is a manifestation of knowledge and skills possessed. In this context, an employee's knowledge will greatly affect employee performance. And it can be concluded that the higher level of an employee's level of education will affect the improvement of employee performance.

In line with the results of previous research Muhammad Triyono (2009) with the title "Influence Some Factors Against Work Performance Employees of Meteorology and Geophysics Agency". Factors analyzed were knowledge, skill, work experience, and technological wear using multiple regression analysis method. The result of this research concludes that knowledge, skill, work experience and technology mastery have a significant effect on job performance, and the most dominant is knowledge.

\section{Influence Skills $\left(\mathbf{X}_{2)}\right.$ Against Employee Performance}

From the results of data analysis using SPSS version 21 indicates that the variable skill with partial $r$ 0,258 with a significant level of 0.005 which means that skills have an influence on employee performance at the District Office Tamalanrea Makassar. It can be concluded that the more frequent follow-training will influence the improvement of employee performance at Tamalanrea District Office Makassar. According to Hadi Pranata AF (1998) work expertise (professional) is a basic pedagogy for employee performance, in which skill is part of the skill. High employee skills will result in high employee performance as well, vice versa. It means that the skills affect the employee performance. According to Andi Astuty (2006) with the title "The Influence of Competence on Employee Work Achievement at BAPPEDA Office of South Sulawesi Province" with the result of research that the skill have dominant and significant influence to the employee performance and indicate that the employee is always directed to improve the skill by mengacy on the progress of science knowledge.

\section{Influence of Self-concept / attitude ( $X_{3)}$ Against Employee Performance}

Behavior of employee attitudes attitude attached to self that aims to achieve optimal work performance. The indicators are: attitudes towards job security, opportunities and attitudes towards employment, attitudes toward goals to be achieved, the attitude toward performance appraisals, attitude to the task or job.

From result of data analysis by using Program SPSS version 21,0 indicate that self concept variable with $\mathrm{r}$ partial 0,291 with sig. 0,010, which means that the concept of self is having a positive influence on employee performance at the District Office Tamalanrea Makassar. It can be drawn a conclusion that the length of the employee's work can not guarantee, can influence employee performance at the District Office Tamalanrea Makassar. Experience high if it is not supported by the level of education it will not produce the professionalism and work performance of employees. Attitudes / behavior employees greatly affect employees in performance, this will encourage the leadership by providing additional rewards in accordance with the performance of employees. This is in accordance with the opinion of Yuniarsih and Suwanto (2008: 121) that the incentive in this respect is a strategy undertaken by organizations aimed at improving. With the rewards in the form of incentives or bonuses, employees will be encouraged to behave as optimally as possible and will provide the best in working to improve job performance. Similarly, the research proposed by Fitriyandi (2002) with the title Influence of Skill Competence, Knowledge, Ability in Human Resource Development on Achievement of PD. Build Banua South Klaimantan Province. The results showed that the variables Competence (skills, knowledge and abilities) partially affect the improvement of employee performance.

\section{Effect of Personal Characteristics $\left(\mathbf{X}_{4}\right)$ Against Employee Performance}

Personal characteristics is the mastery level of knowledge and skill to work that can be measured by the length of service and level of knowledge and skills they have.

From the results of data analysis using SPSS version 21 indicates that the variable personal characteristics of employees with partial r 0.144 , referring to the magnitude of the significant value of 0,147 is greater than 0.05 , 
it can be concluded that the relationship between personal characteristics and performance employees are not significant, so the hypothesis is rejected, but the personal characteristics variables have a positive influence on the improvement of self concept / attitude is the mastery level of knowledge and skill to work that can be measured by the length of service and level of knowledge and skills they have.

\section{Conclusion}

\section{Conclusions And Suggestions}

Based on the results of the analysis and discussion of research results, the researchers conclude as follows: From result of research indicate that variable of Knowledge, Skill, Self Concept / Attitude simultaneously influential positively significant to performance of officer of Office Tamalanrea Makassar Subdistrict. The most dominant factor influencing the performance of employees of Tamalanrea Makassar District Office is Skill. With the skill possessed by the employee can help his work to be completed more quickly in his work due to more diligent, creative and can create new things in completing tasks and responsibilities. According to the results of multiple regression calculation determination coefficient $\mathrm{R}^{2}$ ( $\mathrm{R}$ Square) shows that all independent variables together influential. While the correlation coefficient shows a very strong relationship between the independent variable with the dependent variable. Simultaneously and partially knowledge, skill, self concept / attitude have an effect on signifikan to performance of officer of Tamalanrea Makassar Subdistrict Office.

\section{Suggestion}

Tamalanrea Makassar District Office always improves the performance of employees through the improvement of Knowledge, especially human resources, Skills, self concept / attitude towards all employees. Should be held education and training on an ongoing basis, to be able to increase the level of knowledge so as to further spur employee morale and performance at the Official Office Tamalanrea Makassar. Knowledge / Education as one way in the implementation of duties and responsibilities of employees who can not be separated from the knowledge that must be owned by every employee at the Office Tamalanrea Makassar District in order to create maximum performance and can improve the performance of employees. To every employee at Tamalanrea Makassar District Office in improving the performance of permanent employee refers to the work skill in order to encourage the creative staff, have innovation with new things in completing their duty and still have high loyalty to their work.

\section{BOOKS}

\section{Bibliography}

[1]. Armstrong, Michael. 2004. Performance Management. Interpreter: Toni Setiawan. Tugu Publisher. Yogyakarta.

[2]. Bacal, Robert. 2005. Performance Management. Interpreting: Surya Dharma \& Yanuar Irawan. PT. Gramedia Pustaka Utama. Jakarta.

[3]. Donovan, F. \& A.C. Jackson. 1991. Managing Human Service Organizations. N.Y: Prentice Hall, New York.

[4]. Dharma, Surya. 2005. Performance Management; The Philosophy of Theory and Its Application, the Student Literature. Yogyakarta.

[5]. Dwiyanto, Agus 1995. Leadership as Science and Art. Liberty. Yokyakart. 1995. Performance Assessment of Public Service Organizations. Fisipol UGM. Yogyakarta.

[6]. Gibson, James L. 1990. Organizational Behavior, Structure, Process. Erland. Jakarta.

[7]. Gibson, Ivancevich Donnelly. 1996. Organizational Behavior of Process Structure. Translation: Nunuk Adiarni. Binarupa Aksara. Jakarta.

[8]. Gomes, Fautino Cardosa. 2002. Human Resource Management. Andi Offset. Yokyakarta.

[9]. Hasibuan, Malayu S.P. 2006. Human Resource Management (Revised Edition). Earth Script. Jakarta.

[10]. Mangkunegara, A.A. Anwar Prabu. 2005. Evaluation of HR Performance. Refika Aditama. Bandung. .2003. Planning and Development of Human Resources. Refika Aditama. Bandung.

[11]. Mitrani, Alain. 1995. Competence Based Human Resource Management (translation). PT. Intermasa. Jakarta.

[12]. Murgiyono. 2002. Basic Competence of Civil Servants, Concept of Thought Competency Based Human Resource Management. Jakarta.

[13]. Murphy, Kevin R. Jeanette N. Cleaveland. 1995. Understanding Performance Appraisal: Social, Organization and Goal-Based Perspectives. Sage Publications, California.

[14]. Musanef. 1993. Indonesian Personnel Management. Holy mountain. Jakarta.

[15]. Mustopadidjaja A.R. 2003. Public Policy Process Management, Formulation, Implementation, and Performance Evaluation. LAN RI. Jakarta.

[16]. Palan, R. 2007. Competency Management. Technique Implementing Competence-Based Human Resource Management to Improve Competitiveness of Organization. Translator: Octa Melia Jalal. PPM Publisher. Jakarta.

[17]. Prawirosentono, Suryadi. 1990. Human Resource Management: Employee Performance Policy, Tips for Towards a Competitive Organization in the World Free Trade. BPFE. Yogyakarta.

[18]. Prayitno, Widodo and Suprapto. 2002. Standardization of Civil Servant Competencies Towards a Global Globalization Era. Series of Working Papers Volume II Number 05. BKN Research and Development Center. Jakarta.

[19]. Rivai, Veithzal., And Basri, Ahmad Fawzi Mohd. 2005. Performance Appraisal. PT. Raja Grafindo Persada. Jakarta.

[20]. Robbins, P. Stephen. 1994. Organizational Theory: Structure, Design \& Application. Translation. Arcan, Jakarta. . 2003. Organizational Behavior. PT. Indesk, Translation Group. Gramedia, Volume 1. Jakarta. 2007. Organizational Behavior. Edition 10. Translation. PT. Macanan Jaya Cemerlang. Jakarta. 
[21]. Ruky, Achmad, S. 2004; Performance Management System. PT. Gramedia Pustaka Utama. Jakarta.

[22]. Sagala, H. Syaiful. 2000. The Administration of Contemporary Education. Bandung. Sangkala. 2007. Knowledge Management PT. Raja Grafindo Persada. Jakarta.

[23]. Sedarmayanti. 2001. Human Resources and Work Productivity, Mandar Maju. Bandung., 2003. Good Governance in the Framework of Regional Autonomy, Efforts to Build Effective and Efficient Organizations Through Restructuring and Empowerment. Mandar Maju. Bandung.

[24]. Siagian, Sondang P. 1992. Human Resource Management. Earth Script. Jakarta.

[25]. Siagian, Sondang P. 2005. Development Administration; Concepts, Dimensions and Strategies. PT. Earth Script. Jakarta.

[26]. Simamora, Henry. 2003. Human Resource Management, Issue III. STIE YKPN. Jakarta.

[27]. Simanjuntak, Payaman. J. 2005. Performance Management and Evaluation, Jakarta: Faculty of Economics UI.

[28]. Sinambela, Lijan Poltak. 2007. Public Service Reform; Theory, Policy and Implementation. PT. Earth Script. Jakarta.

[29]. Sugiyono. 2001. Administrative Research Methods. Alfabeta. Bandung. , 2006. Research Methods Administration (Revised Edition). Alfabeta. Bandung.

[30]. Wibowo, 2007. Performance Management, Jakarta: PT. Raja Grafindo Persada.

[31]. Thesis and ARTICLES Emmyah. 2007. Analysis of Employee Performance Factors At Ujung Pandang State Polytechnic. Makassar: STIA-LAN RI Jacinta F. Rini. 2002. Self-concept. (Http: /www.epsikologi.com / / adult / 1,60502.htm. (Accessed on March 12, 2009) Postgraduate Program STIA LAN Makassar, 2006. Thesis Writing Guide. Makassar.

[32]. Center for Research and Development of the State Personnel Agency. 2004. Preparation of Guidelines for Measurement of Civil Servant Competencies in Structural Positions. (Http: //www.bkn.go.id). (Accessed on March 25, 2009)

[33]. Sutoto, D. 2004. Dimensions of Competency Level. Article (http://www.petra.ac.id/ puslit/journals/dir.php). (Accessed on April $25,2008)$

\section{LAWS AND REGULATIONS}

[34]. Law Number 43 Year 1999, on the Principles of Personnel of the Republic of Indonesia.

[35]. Government Regulation No. 100/2000 on the Appointment of Civil Servants in Structural Positions 